\title{
Acute Lymphoblastic Leukemia in Routine Practice: A Turkish Multicenter Study
}

\author{
Rutin Uygulamada Akut Lenfoblastik Lösemi: Türkiye'den Çok Merkezli Bir Çalışma
}

(D) Rafiye Çiftçiler1, (D) Ömür Gökmen Sevindik², (D) Ali İrfan Emre Tekgündüz³, (D) Mehmet Ali Erkurt4, (D) Filiz Vural5, (D) Burhan Turgut6, (D) Leylagül Kaynar7, (D) Bahriye Payzın², (D) Mehmet Hilmi Doğu99, (D) Volkan Karakuş10, (D) Fevzi Altuntaş11, (D) Yahya Büyükaşık1,

(D) Fatih Demirkan12

\begin{abstract}
${ }^{1}$ Hacettepe University Faculty of Medicine, Department of Hematology, Ankara, Turkey
${ }^{2}$ Medipol University Hospital, Clinic of Hematology, Istanbul, Turkey

${ }^{3}$ Memorial Bahçelievler Hospital, Clinic of Hematology, istanbul, Turkey

4 inönü University Faculty of Medicine, Department of Hematology, Malatya, Turkey

${ }^{5}$ Ege University Faculty of Medicine, Department of Hematology, Izmir, Turkey

${ }^{6}$ Namık Kemal University Faculty of Medicine, Department of Hematology, Tekirdağ, Turkey

7 Erciyes University Faculty of Medicine, Department of Hematology, Kayseri, Turkey

8izmir Atatürk Training and Research Hospital, Clinic of Hematology, Izmir, Turkey

9 istanbul Training and Research Hospital, Clinic of Hematology, Istanbul, Turkey

${ }^{10}$ Muğla Sıtkı Koçman University Faculty of Medicine, Department of Hematology, Muğla, Turkey

${ }^{11}$ Ankara Oncology Training and Research Hospital, Clinic of Hematology, Ankara, Turkey

12Dokuz Eylül University Faculty of Medicine, Department of Hematology, Izmir, Turkey
\end{abstract}

\section{Abstract}

Objective: Significant developments occurred in the clinical management of acute lymphoblastic leukemia (ALL) in adults in recent decades. However, treatment results are still not satisfactory, especially in routine practice. The objective of this study was to evaluate the general clinical features, treatment details, and outcomes of a large group of patients followed in multiple centers in Turkey with a diagnosis of ALL.

Materials and Methods: A retrospective analysis of the data of patients with ALL was made, the patients having been diagnosed and treated between January 2003 and June 2017 by different protocols in the hematology clinics of ten different centers. A total of 288 patients, aged between 17 and 76 years old, were included in the study. In this retrospective multicenter analysis of patients with ALL, classification of patients was performed based on treatment period, Philadelphia chromosome positivity, treatment regimen, and administration of allogeneic hematopoietic stem cell transplantation (allo-HSCT).

Results: The majority of cases were B-cell in origin, while 224 patients had B-ALL and 64 of the patients had T-ALL. Median follow-up duration for all patients was 18.2 months (range: 0.03-161 months). Philadelphia chromosome positivity was determined in 49 patients (21.9\%), and 54 patients (18.8\%) were receiving allo-HSCT. After induction chemotherapy, 219 patients (76.0\%) achieved complete

\section{Öz}

Amaç: Son yıllarda erişkinlerde akut lenfoblastik löseminin (ALL) tedavi yönetiminde önemli gelişmeler meydana gelmiştir. Bununla birlikte, özellikle rutin uygulamada tedavi sonuçları hala tatmin edici değildir. Çalışmanın amacı, Türkiye'de birden fazla merkezde takip edilen geniş bir ALL hasta grubunun genel klinik özelliklerini, tedavi özelliklerini ve sağkalım sonuçlarını değerlendirmektir.

Gereç ve Yöntemler: Ocak 2003 ile Haziran 2017 tarihleri arasında on farklı merkezdeki hematoloji kliniğinde tanı konulan ve farklı protokollerle tedavi edilen ALL hastalarının verilerinin retrospektif analizi yapıldı. Çalışmaya yaşları 17 ile 76 arasında değişen toplam 288 hasta dahil edildi. Bu çalışmada ALL'li hastalar tedavi periyoduna, Philadelphia kromozom pozitifliğine, tedavi protokolü ve allojenik hematopoetik kök hücre nakli (AHKHN) yapılıp yapılmamasına göre sınıflandırıldı.

Bulgular: Olguların 224'ü B-ALL, 64'ü T-ALL idi. Tüm hastalar için ortanca takip süresi 18,2 ay (dağılım, 0,03-161 ay) idi. Philadelphia kromozomu $(\mathrm{Ph}+)$ pozitifliği $49(\% 21,9)$ hastada saptandı ve 54 hastaya $(\% 18,8)$ AHKHN yapıldığı izlendi. İndüksiyon kemoterapisinden sonra 219 hasta (\%76) tam remisyona girdi, 32 hasta tedaviye refrakter $(\% 11,2)$ olarak değerlendirildi, 37 hastada ise $(\% 12,8)$ mortalite gözlendi. Ortanca genel sağkalım 47,7 ay (\%95 güven aralığı: 36,1$59,2)$ ve ortanca hastalıksız sağkalım tüm hastalar için 23,4 ay $(\% 95$ güven aralığı: 6,7-40,0) idi.

๑Copyright 2019 by Turkish Society of Hematology

Turkish Journal of Hematology, Published by Galenos Publishing House

口: Address for Correspondence/Yazışma Adresi: Rafiye ÇifTÇiLER, M.D.,

Hacettepe University Faculty of Medicine, Department of Hematology, Ankara, Turkey

Phone : +905055831798

口触 E-mail : rafiyesarigul@gmail.com ORCID-ID: orcid.org/0000-0001-5687-8531

Received/Geliş tarihi: January 03, 2019 Accepted/Kabul tarihi: May 24, 2019 
Abstract

remission, 32 patients (11.2\%) were evaluated as treatment refractory, and 37 patients (12.8\%) were deceased. Median overall survival was 47.7 months (95\% confidence interval: $36.1-59.2)$ and median disease-free survival was 23.4 months (95\% confidence interval: 6.740.0) for all patients.

Conclusion: Multicenter studies are extremely important for defining the specific clinical features of a particular disease. The results of this study will make a significant contribution to the literature as they reflect real-life data providing valuable information about the Turkish ALL patient profile.

Keywords: Acute lymphoblastic leukemia, Pediatric regimen, Pediatric-inspired regimen, Philadelphia chromosome $\ddot{0} \mathrm{z}$

Sonuç: Sonuç olarak, çok merkezli çalışmalar, belirli bir hastalığın spesifik klinik özelliklerini tanımlamak için büyük öneme sahiptir. Bu çalışmanın sonuçları, Türk ALL hasta profili hakkında değerli bilgiler sağlayan gerçek hayat verilerini yansıttığı için literatüre önemli bir katkı sağlayacaktır.

Anahtar Sözcükler: Akut lenfoblastik lösemi, Pediatrik rejim, Pediatrik rejimden ilham alan rejim, Philadelphia kromozomu

\section{Introduction}

Significant developments have occurred in the clinical management of acute lymphoblastic leukemia (ALL) in adults in the last decades. However, treatment results are still not satisfactory, especially in routine practice. Disease biology, higherrisk leukemia genetics, absence of sufficiently effective therapies, noncompliance with treatment, and intolerance of chemotherapy are the main reasons for unsatisfactory results [1]. Another challenge in adult ALL treatment is the lack of a standardized regimen. However, gradual stable improvement has been observed recently in adult ALL as a result of adopting pediatric-inspired regimens, better identification of high-risk patients and early referral for allogeneic hematopoietic stem cell transplantation (allo-HSCT), increased availability of donors, and the inclusion of minimal residual disease (MRD) in ALL treatment decisions $[2,3]$. The objective of this study was to evaluate the general clinical features, treatment details, and outcomes of a large group of patients with ALL followed in multiple centers in Turkey.

\section{Materials and Methods}

\section{Study Design and Data Collection}

A retrospective analysis was made of the data of ALL patients who were diagnosed and treated with different protocols in ten hematology clinics between January 2003 and June 2017. Patients were classified by treatment period, Philadelphia chromosome positivity $(\mathrm{Ph}+)$, treatment regimen, and administration of allo-HSCT. A total of 288 patients were included from the ten participating centers. The primary outcome was overall survival $(\mathrm{OS})$ and secondary outcomes were complete remission (CR) rate and disease-free survival (DFS).

The presence of ALL was diagnosed by the detection of $\geq 20 \%$ blasts in the bone marrow. Immunophenotype was detected using flow cytometry (peripheral blood or bone marrow) or immunohistochemical techniques (bone marrow biopsy or aspiration) for each patient. The presence of the Ph chromosome/ $\mathrm{BCR}-\mathrm{ABL}$ fusion transcript was investigated using conventional cytogenetic analysis (karyotyping) on bone marrow samples. Quantitative polymerase chain reaction (RQ-PCR) was performed to monitor $\mathrm{BCR} / \mathrm{ABL}$ fusion transcripts during follow-up.

Intensive regimens were classified as pediatric regimens (BFM, Dana Farber), pediatric-inspired chemotherapy (DFClALL consortium protocol, CALGB, Linker-4 regimen, MRC UKALLXII/ECOG-2993, GMALL), or adult intensive chemotherapy (HYPERCVAD, CODOX-M, CHOEP, GRAALL-2003, FLAG, FLAGIDA). Nonintensive regimens were classified as POMP and EWALL regimens. A total of 86 patients $(29.9 \%)$ were treated with a pediatric regimen, $84(29.1 \%)$ with pediatric-inspired chemotherapy, 105 (36.5\%) with adult intensive chemotherapy, and $13(4.5 \%)$ with a nonintensive regimen. At the time of diagnosis, patients with good general condition and good ECOG performance status were treated with intensive regimens such as a pediatric regimen, pediatric-inspired chemotherapy, or adult intensive chemotherapy. Patients with poor general condition and poor ECOG performance status were given nonintensive regimens such as EWALL and POMP chemotherapy protocols. The treatment regimens are presented in Table 1.

All patients received growth factor support during chemotherapy, and anti-infective prophylaxis with fluconazole (400 mg/day), valacyclovir (2x500 mg/day), and trimethoprim/ sulfamethoxazole (160/800 mg, 2 days a week) was used in the intensive chemotherapy group. All patients underwent bone marrow aspiration and biopsy on median day 28 of treatment (range: days 18-48) to evaluate patients' responses to induction chemotherapy. CR was defined as $<5 \%$ blasts in regenerating bone marrow without the finding of extramedullary residual disease.

All of the ethical considerations were strictly followed in accordance with the 1964 Helsinki Declaration. As standard care/action of the hospitals has been recognized from the 
patient records that all of the studied patients gave informed consent at the time of admission to the hospital and before the administration of chemotherapy and other relevant diagnostic/ therapeutic standards of care.

\section{Statistical Analysis}

Demographic characteristics were presented using proportions and medians (minimum-maximum) for categorical and continuous variables, respectively. Statistical comparisons were made using the chi-square test for categorical data. Survival analyses were made using the Kaplan-Meier test. The log-rank test was applied to compare survival data. OS was calculated from the date of diagnosis to death for any reason. Surviving patients were counted on the date of the final follow-up examination. DFS was calculated from the date of CR to relapse or death in

\begin{tabular}{|c|c|}
\hline Treatment regimens & $\mathbf{n}$ \\
\hline \multicolumn{2}{|l|}{ Intensive regimen } \\
\hline \multicolumn{2}{|l|}{ - Pediatric regimen } \\
\hline BFM [4] & 71 \\
\hline Dana Farber [5] & 15 \\
\hline \multicolumn{2}{|l|}{ - Pediatric-inspired chemotherapy } \\
\hline DFCl-ALL [6] & 25 \\
\hline CALGB [7] & 51 \\
\hline Linker-4 regimen [8] & 3 \\
\hline MRC UK-ALLXII/ECOG-2993 [9] & 2 \\
\hline GMALL [10] & 3 \\
\hline \multicolumn{2}{|l|}{ - Adult intensive chemotherapy } \\
\hline $\begin{array}{l}\text { HYPERCVAD (hyperfractionated cyclophosphamide, } \\
\text { vincristine, doxorubicin, and dexamethasone } \\
\text { alternating with high-dose methotrexate and } \\
\text { cytarabine) [11] }\end{array}$ & 92 \\
\hline $\begin{array}{l}\text { CODOX-M (cyclophosphamide, vincristine, } \\
\text { doxorubicin, high-dose methotrexate/ifosfamide, } \\
\text { etoposide, and high-dose cytarabine) [12] }\end{array}$ & 1 \\
\hline $\begin{array}{l}\text { CHOEP (cyclophosphamide, doxorubicin, vincristine, } \\
\text { etoposide, prednisone) [13] }\end{array}$ & 1 \\
\hline GRAALL-2003 [14] & 4 \\
\hline $\begin{array}{l}\text { FLAG (fludarabine, cytarabine, granulocyte colony- } \\
\text { stimulating factor) [15] }\end{array}$ & 2 \\
\hline $\begin{array}{l}\text { FLAG-IDA (fludarabine, cytarabine, granulocyte } \\
\text { colony-stimulating factor, idarubicin) [15] }\end{array}$ & 5 \\
\hline \multicolumn{2}{|l|}{ Nonintensive regimen } \\
\hline EWALL [16] & 4 \\
\hline $\begin{array}{l}\text { POMP (mercaptopurine, vincristine, methotrexate, } \\
\text { prednisone) [17] }\end{array}$ & 9 \\
\hline Total & 288 \\
\hline \multicolumn{2}{|c|}{$\begin{array}{l}\text { BFM: Berlin-Frankfurt-Munster, DFCI: Dana Farber Cancer Institute, CALGB: Cancer } \\
\text { and Leukemia Group B, ECOG: Eastern Cooperative Oncology Group, EWALL: European } \\
\text { Working Group on Adult ALL, MRC: Medical Research Council, n: number of patients, } \\
\text { GMALL: German Multicenter ALL Study Group, GRALL: Group for Research on Adult } \\
\text { Acute Lymphoblastic Leukemia. }\end{array}$} \\
\hline
\end{tabular}

remission. Patients surviving in remission were counted on the date of the final follow-up examination. Univariate analyses of the differences in OS and DFS were applied using log-rank tests. Receiving allo-HSCT, age ( $\leq 30$ years), sex (male), Ph chromosome (negativity), treatment regimen (pediatric regimen vs. other regimens), and time period (2011-2017 vs. 2003-2011) were evaluated as prognostic factors. Univariate comparisons with a $p$-value of $<0.15$ were included in the multivariate analyses, in which $p<0.05$ was considered statistically significant. Cox regression analysis was performed to study the simultaneous impact of selected factors on survival. Values of $p<0.05$ were accepted as statistically significant. The statistical analyses were conducted using SPSS 17 (SPSS Inc., Chicago, IL, USA).

\section{Results}

\section{Patient and Treatment Group Characteristics}

The study included 288 patients, consisting of 173 males and 115 females with a median age of 34 (range: $17-95$ years). The majority of cases were B-cell in origin; $224(77.8 \%)$ patients had B-ALL and 64 (22.2\%) had T-ALL. Philadelphia chromosome positivity $(\mathrm{Ph}+)$ was determined in $49(21.9 \%)$ patients. All patients with $\mathrm{Ph}+\mathrm{ALL}$ were diagnosed after 2005. Imatinib was added to the chemotherapy protocol for $47 \mathrm{Ph}+\mathrm{ALL}$ patients (95.9\%). Rituximab was added to the chemotherapy protocol for patients with CD20-positive B-cell ALL. Allo-HSCT was administered to $54(18.8 \%)$ patients. The clinical characteristics of the ALL patients are given in Table 2.

Table 2. Baseline characteristics of acute lymphoblastic leukemia patients.

\begin{tabular}{|c|c|}
\hline & n (range or percentage) \\
\hline Age, years & $34(17-95)$ \\
\hline Sex, F/M & $115 / 173$ \\
\hline $\begin{array}{l}\text { Follow-up duration for all and surviving } \\
\text { patients, months }\end{array}$ & $\begin{array}{l}18.3(0.03-161) \text { and } 23.3 \\
(0.03-161)\end{array}$ \\
\hline T-ALL / B-ALL & $64(22.2 \%) / 224(77.8 \%)$ \\
\hline $\begin{array}{l}\text { Ph-positive }(\mathrm{Ph}+\text { ) } \mathrm{ALL} \\
\text { (among B-ALL cases) }\end{array}$ & $49(21.9 \%)$ \\
\hline Intensive / nonintensive treatment & $275(95.4 \%) / 13(4.5 \%)$ \\
\hline \multicolumn{2}{|l|}{ Treatment protocols* } \\
\hline Pediatric regimen & $86(29.9 \%)$ \\
\hline Pediatric-inspired chemotherapy & $84(29.1 \%)$ \\
\hline Adult intensive chemotherapy & $105(36.5 \%)$ \\
\hline Non-intensive (POMP or EWALL) & $13(4.5 \%)$ \\
\hline *Tyrosine kinase inhibitor & 47 patients $(95.9 \%)$ \\
\hline Allo-HSCT & $54(18.75 \%)$ \\
\hline \multicolumn{2}{|c|}{$\begin{array}{l}\text { *Imatinib was added to the chemotherapy protocol for Philadelphia-positive ALL } \\
\text { patients. Rituximab was added to the chemotherapy protocol for CD20-positive B-cell } \\
\text { ALL. } \\
\text { B-ALL: B-cell acute lymphoblastic leukemia, CR: complete remission, n: number of } \\
\text { patients, T-ALL: T-cell acute lymphoblastic leukemia. }\end{array}$} \\
\hline
\end{tabular}




\section{Overall Outcomes}

The median follow-up period for all patients was 18.2 months (range: 0.03-161.0 months). After induction chemotherapy, 219 patients (76.0\%) achieved complete remission, 32 patients $(11.2 \%)$ were evaluated as treatment refractory, and 37 patients (12.8\%) were deceased. Median OS was 47.7 months (95\% confidence interval (CI): 36.1-59.2) and median DFS was 23.4 months (95\% Cl: 6.7-40.0) for all patients. The 3-year OS and DFS rates were $56 \%$ and $45 \%$, respectively. The 5 -year OS and DFS rates were $43 \%$ and $35 \%$, respectively.

Median OS was 33.9 months (95\% Cl: 17.4-50.3) for Ph+ ALL patients and 73.7 months (95\% Cl: 33.9-113.5) for Ph-negative (Ph-) ALL patients $(\mathrm{p}=0.48)$. Median DFS was 7.1 months $(95 \%$ $\mathrm{Cl}$ : 5.0-9.3) for $\mathrm{Ph}+\mathrm{ALL}$ patients and 34.6 months $(95 \% \mathrm{Cl}$ : 16.0-53.2) for Ph- ALL patients. DFS was statistically significant longer in $\mathrm{Ph}-$ patients than $\mathrm{Ph}+$ patients $(\mathrm{p}=0.008)$. The 5 -year OS was 50\% in Ph- patients and 16\% in $\mathrm{Ph}+$ patients, respectively. The 5-year DFS was 35\% in Ph-patients and $11 \%$ in $\mathrm{Ph}+$ patients (Figure 1).

Median OS was 53.4 months (95\% Cl: 37.9-63.5) in patients receiving a pediatric regimen and 42.9 months (95\% $\mathrm{Cl}$ : $19.9-$ $66.6)$ in patients receiving other intensive regimens $(p=0.05)$. Median DFS was 16.9 months (95\% Cl: 3.9-23.6) in patients receiving a pediatric regimen and 13.3 months (95\% Cl: $6.5-$ $20)$ in patients receiving other intensive regimens $(p=0.78)$. The 5-year OS was $45 \%$ in patients who received a pediatric regimen and $43 \%$ in patients who received other intensive regimens. The 5 -year DFS was $23 \%$ in patients who received a pediatric regimen and $25 \%$ in patients who received other intensive regimens (Figure 2).

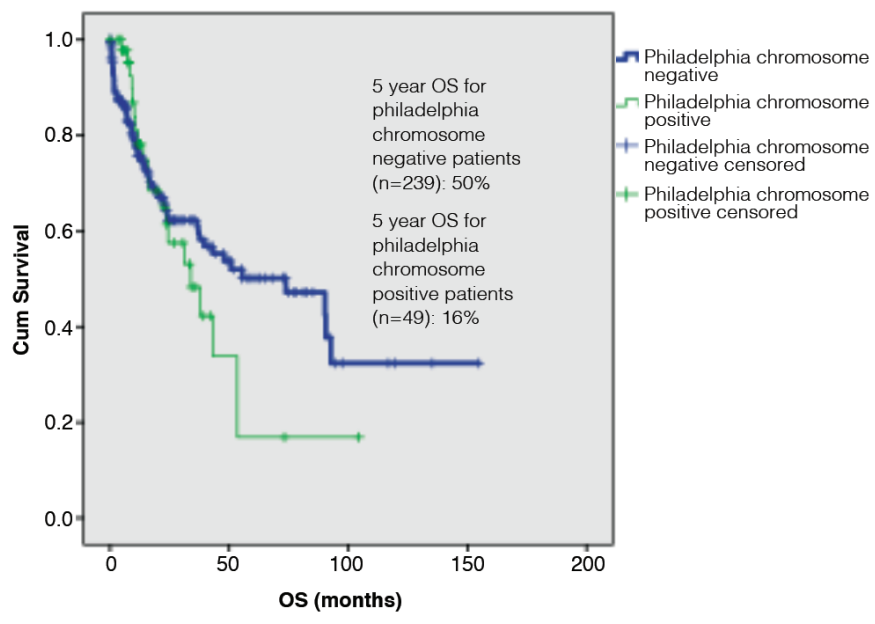

When only the patients under 30 years of age were analyzed, no significant difference was determined between pediatric and other intensive regimens in terms of OS and DFS. The 3 -year OS was 77\% in patients under 30 years of age who received a pediatric regimen and $66 \%$ in patients who received other intensive regimens. The 5 -year OS was 53\% in patients under 30 years of age who received a pediatric regimen and $56 \%$ in patients who received other intensive regimens $(p=0.68)$. The 3 -year DFS was $54 \%$ in patients under 30 years of age who received a pediatric regimen and $45 \%$ in patients who received other intensive regimens. The 5 -year DFS was $36 \%$ in patients under 30 years of age who received a pediatric regimen and $31 \%$ in patients who received other intensive regimens $(p=0.84)$.

The 2-year periods between 2003 and 2017 for treatment regimens are shown in Figure 3. From 2003 to 2017, the usage of pediatric regimens increased in ALL patients. The count of patients diagnosed with ALL and the treatment protocols used were observed to vary over time. While adult intensive regimens were used more commonly in the past, there is a tendency to use pediatric regimens at present time.

The follow-up dates between January 2003 and April 2017 were divided into 7 treatment periods (Table 3 ). There was no statistically significant improvement in OS according to time among the ALL patients $(p=0.58)$. There was no statistically significant improvement in DFS according to time for ALL patients $(p=0.92)$. The success of CR did not differ significantly over the years $(p=0.49)$. OS and DFS were higher between the years of 2007 and 2011 compared to other periods. OS and DFS were higher in the 2007-2011 period, but not at a statistically significant level. The 5-year OS rate was 73\% in 2007-2011 and

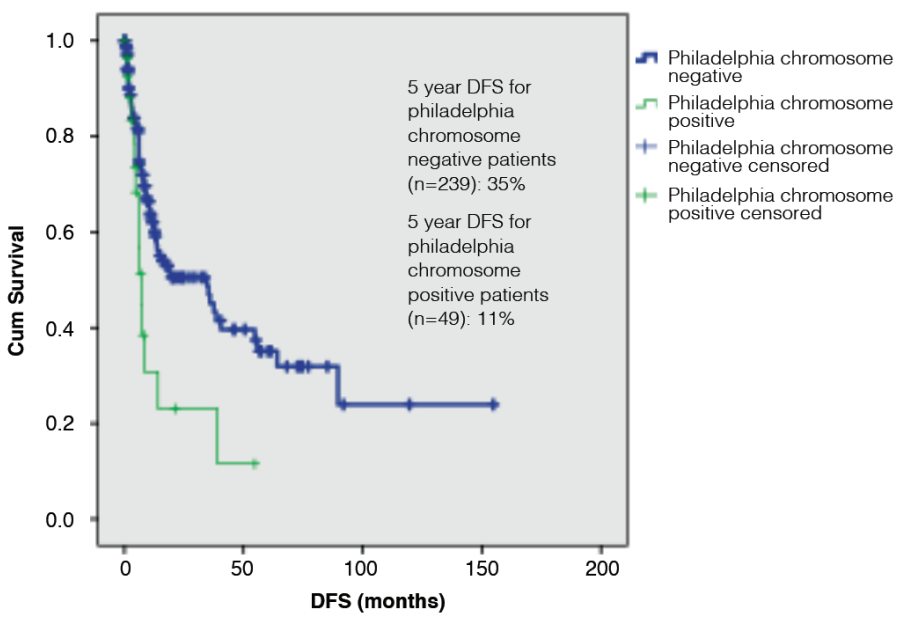

Figure 1. Overall survival $(p=0.48)$ and disease-free survival $(p=0.008)$ for acute lymphoblastic leukemia patients according to Philadelphia chromosome status.

OS: Overall survival, DFS: disease-free survival. 


\begin{tabular}{|c|c|c|c|c|c|c|c|c|c|}
\hline Time period & $\begin{array}{l}2003- \\
2005\end{array}$ & $\begin{array}{l}2005- \\
2007\end{array}$ & $\begin{array}{l}2007- \\
2009\end{array}$ & 2009-2011 & 2011-2013 & $\begin{array}{l}2013- \\
2015\end{array}$ & $\begin{array}{l}2015- \\
2017\end{array}$ & Total & p \\
\hline CR (\%) & $80 \%$ & $64 \%$ & $57.9 \%$ & $73 \%$ & $69.8 \%$ & $77.2 \%$ & $77.9 \%$ & $73.2 \%$ & 0.49 \\
\hline $\begin{array}{l}\text { DFS, months, median } \\
(95 \% \mathrm{Cl})\end{array}$ & $\begin{array}{l}10.3 \\
(0.69-20)\end{array}$ & $\begin{array}{l}13.3 \\
(10-16.5)\end{array}$ & $\begin{array}{l}64.1 \\
(0-139.6)\end{array}$ & $\begin{array}{l}54.5 \\
(0-129)\end{array}$ & $\begin{array}{l}39 \\
(25.3-52.6)\end{array}$ & $\begin{array}{l}13.6 \\
(2.4-24.7)\end{array}$ & $\begin{array}{l}17.0 \\
(13.5-20.5)\end{array}$ & $\begin{array}{l}18.9 \\
(2-35.7)\end{array}$ & 0.92 \\
\hline$\% \pm \mathrm{SE}$ at 3 years & $33.3 \pm 13.6$ & $19 \pm 11.25$ & $54.5 \pm 15$ & $51.1 \pm 12$ & $57.6 \pm 8.7$ & $43.8 \pm 8$ & $52.1 \pm 8$ & $45 \pm 4.2$ & \\
\hline $\begin{array}{l}\text { OS, months, median } \\
(95 \% \mathrm{Cl})\end{array}$ & $\begin{array}{l}53.7 \\
(0-118)\end{array}$ & $\begin{array}{l}22.6 \\
(9.5-35.6)\end{array}$ & $\begin{array}{l}90 \\
(0-182)\end{array}$ & $\begin{array}{l}60.0 \\
(43.2-76.8)\end{array}$ & $\begin{array}{l}53.4 \\
(33.8-73)\end{array}$ & $\begin{array}{l}47.7 \\
(25.8-69.5)\end{array}$ & $\begin{array}{l}22.6 \\
(20.2-25.0)\end{array}$ & $\begin{array}{l}43.1 \\
(31.2-55.1)\end{array}$ & 0.58 \\
\hline$\% \pm \mathrm{SE}$ at 3 years & $40.4 \pm 9.3$ & $36.9 \pm 10.6$ & $65.5 \pm 11.6$ & $48.5 \pm 11.3$ & $61.1 \pm 7.3$ & $56.8 \pm 7.3$ & $58 \pm 7.3$ & $56 \pm 3.5$ & \\
\hline
\end{tabular}
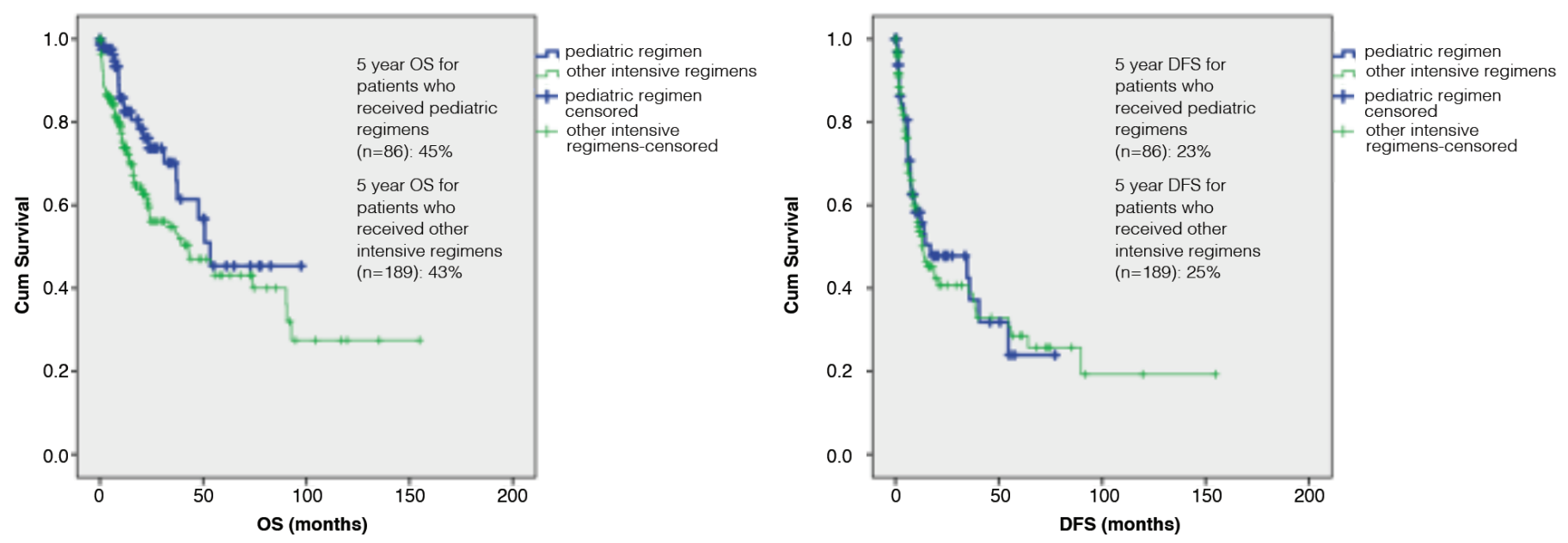

Figure 2. Overall survival $(p=0.05)$ and disease-free survival $(p=0.78)$ for acute lymphoblastic leukemia patients according to pediatric regimens and other intensive regimens.

OS: Overall survival, DFS: disease-free survival.

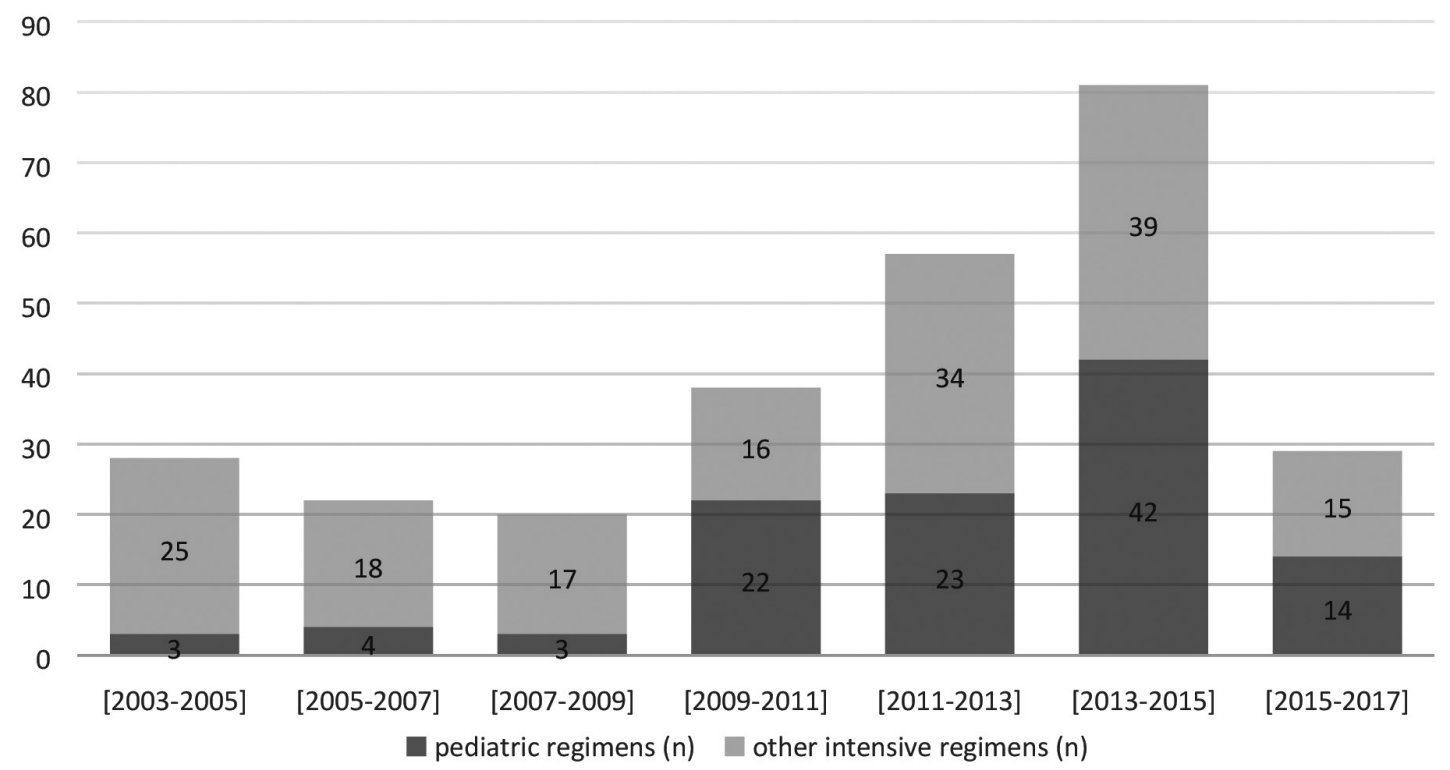

Figure 3. Two-year periods between 2003 and 2017 for treatment regimens. 
$36 \%$ in the remaining period $(\mathrm{p}=0.08)$. The 5 -year DFS rate was $55 \%$ in 2007-2011 and 24\% in the remaining period $(p=0.11)$.

\section{Cox Regression Analyses}

In univariate analyses the variables that affected OS were determined to be receiving allo-HSCT $(p=0.01)$, cellular origin of the disease (B-cell $A L L)(p=0.02)$, patient age ( $\leq 30$ years) $(p=0.001)$, being male $(p=0.03)$, and treatment regimen (receiving a pediatric regimen) $(p=0.05)$ (Table 4$)$. Cox regression analysis revealed patient age $(\leq 30$ years) $(p<0.001)$ and cellular origin of the disease (B-cell origin) $(p=0.04)$ as the parameters predicting $0 \mathrm{~S}$.

In univariate analyses the variables that affected DFS were receiving allo-HSCT $(p=0.02)$, patient age $(\leq 30$ years) $(p=0.02)$, being male $(p=0.10)$, and Ph chromosome negativity $(p=0.009)$. Cox regression analysis did not reveal any parameters predicting DFS.

\section{Discussion}

ALL is one of the most common hematological malignancies in pediatric patients, with a cure rate of approximately $80 \%$. However, in adults, ALL is uncommon and has a bad prognosis [9]. Despite the improvement in CR rates, most adults with ALL will relapse and finally die because of this illness. Although advanced therapy such as allo-HSCT and supportive care for ALL patients has improved the OS rate, unfortunately it is still as poor as $30 \%-40 \%$ at 5 years $[18,19,20]$.

In this study, patients were classified by treatment period, Philadelphia chromosome positivity, treatment regimen, and administration of allo-HSCT. The results consisted of induction therapy and survival outcomes of patients from ten participating centers. A variety of factors were determined that could affect $O S$ and DFS in adult ALL patients, such as Philadelphia chromosome negativity, treatment regimen, younger age, being male, cellular origin of the disease, and receiving allo-HSCT.

$\mathrm{Ph}+\mathrm{ALL}$ is a leukemia mainly encountered in adult patients, and its incidence tends to grow with age [21]. The Ph chromosome marks a group of patients at very high risk, as shown by the data published by a French study in which of 25 patients with $\mathrm{Ph}+\mathrm{ALL}$ only $60 \%$ reached CR after a course of chemotherapy and 4 patients reached CR after salvage chemotherapy. The CR rate was $76 \%$, the mean DFS was 5.6 months, and the mean OS was 10.1 months [22]. Gokbuget et al. [23] reported $50 \mathrm{Ph}+$ patients who had poor responses to age-adjusted chemotherapy compared to $\mathrm{Ph}$ - patients. The remission rate was reported as 19\% for $\mathrm{Ph}+$ patients and 64\% for Ph-patients. In the current study, OS was longer in $\mathrm{Ph}$ - patients than $\mathrm{Ph}+$ patients but there was no statistically significant difference. In addition, DFS was statistically significantly longer in $\mathrm{Ph}$ - patients than $\mathrm{Ph}+$ patients. All patients with $\mathrm{Ph}+\mathrm{ALL}$ were diagnosed after 2005

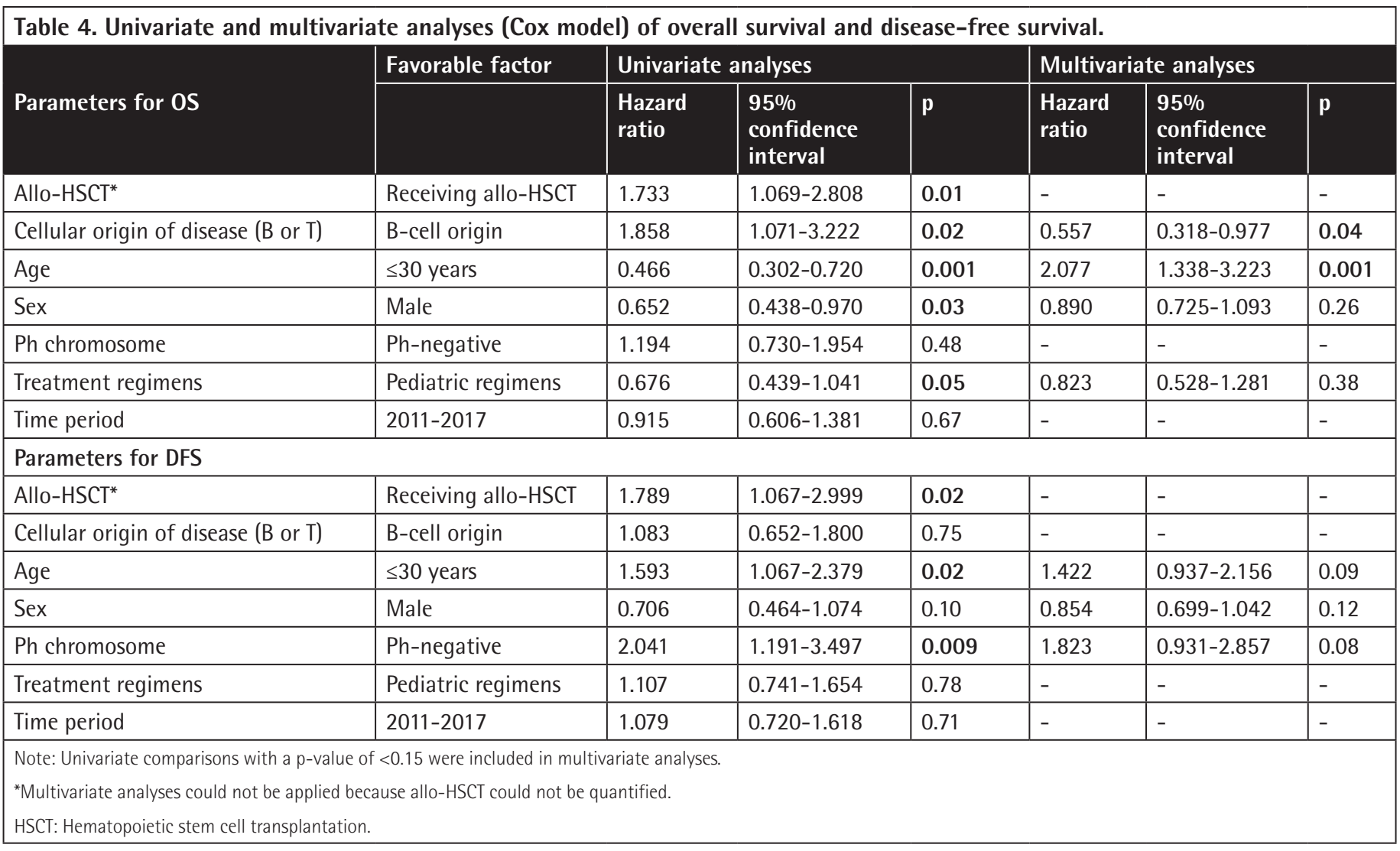


in this study. Imatinib treatment was added to the treatment protocols of $95.9 \%$ of patients with $\mathrm{Ph}+\mathrm{ALL}$. Tyrosine kinase inhibitors are added in most standard ALL protocols for young patients with $\mathrm{Ph}+\mathrm{ALL}$. However, for older patients higher induction mortality rates have been reported with such approaches $[24,25]$. Some studies that examined the use of a combination of tyrosine kinase inhibitors (imatinib or dasatinib) with mild therapy including a steroid with or without vincristine reported CR in the majority of patients with $\mathrm{Ph}+\mathrm{ALL}[26,27]$.

Significant improvements have been achieved in ALL treatment using new clinical protocols. Developments regarding the immunobiology of ALL and better recognition of prognostic factors have resulted in better characterization of risk groups and the tailoring of therapy $[4,5,28]$. In the current study, the followup period between January 2003 and June 2017 was divided into 7 treatment periods. There was no statistically significant improvement in survival outcomes in ALL patients according to these periods. Furthermore, the achievement of CR was not determined to have been improved over time in the overall study period. It is thought that this is due to the fact that new agents are not added to treatment protocols for the treatment of ALL in adults, especially in developing countries. Recent developments in the treatment of ALL need to be used more effectively. Additionally, every ALL patient should be followed with MRD. Treatment options after induction chemotherapy of patients, especially allo-HSCT, should be planned according to the results of MRD follow-up, but unfortunately very few centers in Turkey follow MRD.

Over the recent 40 years, numerous efficacious chemotherapy regimens have been developed for the treatment of $A L L$, mostly based on pediatric regimens. Some prospective trials have compared different regimens in ALL patients. Most progress in ALL treatment has been seen in children and adolescents, while the advancement reported for adults is restricted $[29,30]$. The existing data in terms of tolerability and efficacy of BFM chemotherapy in adults are insufficient $[31,32]$. In a singlecenter study with BFM chemotherapy in adult ALL patients, the CR rate was 90\% with induction chemotherapy and 5-year OS was $62 \%$ [32]. The current study showed that there was a nearly statistically significant difference in $O S$ in patients receiving a pediatric regimen compared to other intensive regimens $(p=0.05)$. Furthermore, there was no statistically significant difference in DFS in patients receiving the original pediatric regimen compared to other intensive regimens $(p=0.78)$. Pediatric regimens did not show a substantial superiority in this study. As in children, the choice is sometimes made to not give optimal dose treatment to adult ALL patients, considering that the patients cannot tolerate it. Therefore, pediatric regimens may not have demonstrated superiority in this study. We think that new agents and new protocols should be considered in the treatment of adult ALL patients.
Allo-HSCT remains an important component in adult ALL therapy, and it is particularly demonstrated to be a main part of treatment for adults with high-risk ALL [1]. In the univariate analysis of the current study, OS and DFS were significantly higher in patients who underwent allo-HSCT. However, only 18.7\% of the total 288 patients received allo-HSCT. In both univariate and multivariate analysis, OS was significantly higher in young patients ( $\leq 30$ years) than in patients aged $>30$ years.

Previous multiple retrospective analyses in adult and pediatric prospective clinical studies comparing the outcomes of ALL treatment in adolescents and young adults have demonstrated the superiority of pediatric regimens in those age groups over adult regimens $[33,34]$. In the current study, the superiority of the pediatric regimens in terms of both OS and DFS could not be demonstrated compared to other intensive regimens. OS was almost statistically significantly better in patients who received pediatric regimens compared to patients who received other intensive regimens, such as pediatric-inspired chemotherapy and adult intensive regimens. In the univariate analyses, however, there was no statistically significant improvement in OS or DFS according to time in ALL patients. DFS was statistically significantly higher in $\mathrm{Ph}$ - patients than $\mathrm{Ph}+$ patients in univariate analyses. However, this was not statistically significant in multivariate analyses. The outcomes of adults with T-cell ALL have improved with recent ALL regimens, and outcomes today are comparable to those of patients with the precursor B-cell subtype $[35,36]$. In this study, patients with B-cell ALL had longer OS than patients with T-cell ALL in univariate and multivariate analyses. However, DFS was not affected by the cellular origin of the disease.

\section{Study Limitations}

This study had some limitations. First, the study was retrospective, and second, cytogenetic results were not obtained for each patient. Third, there were differences in treatment modalities between the centers, so many different types of treatment regimens were used for these ALL patients. Moreover, the infrastructure and quality of each center are different. Hence, it is very difficult to draw conclusions from these heterogeneous results. Searching for an improvement in $C R$ rates in such a heterogeneous group of patients is highly challenging. The retrospective nature and treatment heterogeneity may be a limitation; however, at the same time they are the major strengths of this study. In addition, outside of clinical studies, pediatric protocols may fail to substantially improve outcomes due to excessive toxicity, treatment delays, and dose reductions.

\section{Conclusion}

Multicenter studies are particularly important for defining the specific clinical features of a particular disease. The results of this study can be considered to make a significant contribution 
to the literature because they reflect real-life data providing valuable information about the Turkish ALL patient profile.

\section{Ethics}

Ethics Committee Approval: All of the ethical considerations were strictly followed in accordance with the 1964 Helsinki Declaration. As a standard care/action of the hospitals, it has been recognized from the patient records that all of the studied patients gave informed consent at the time of admission to the hospital and before the administration of chemotherapy and other relevant diagnostic/therapeutic standards of care.

Informed Consent: All of the studied patients gave informed consent at the time of admission to the hospital.

\section{Authorship Contributions}

Surgical and Medical Practices: R.Ç.; Concept: F.D., F.A., Y.B.; Design: Y.B.; Data Collection or Processing: R.Ç., Ö.G.S., A.I.E.T., M.A.E., F.V., B.T., L.K., B.P., M.H.D., V.K., F.A.; Analysis or Interpretation: Y.B.; Literature Search: Y.B.; R.Ç.; Writing: R.Ç.

Conflict of Interest: The authors of this paper have no conflicts of interest, including specific financial interests, relationships, and/or affiliations relevant to the subject matter or materials included.

\section{References}

1. Aldoss I, Stein AS. Advances in adult acute lymphoblastic leukemia therapy. Leuk Lymphoma 2018;59:1033-1050.

2. Dinmohamed $A G$, Szabo $A$, Van der Mark $M$, Visser 0 , Sonneveld $P$, Cornelissen J, Jongen-Lavrencic M, Rijneveld AW. Improved survival in adult patients with acute lymphoblastic leukemia in the Netherlands: a population-based study on treatment, trial participation and survival. Leukemia 2016;30:310-317.

3. Geyer MB, Hsu M, Devlin SM, Tallman MS, Douer D, Park JH. Overall survival among older US adults with ALL remains low despite modest improvement since 1980: SEER analysis. Blood 2017;129:1878-1881.

4. Möricke $A$, Reiter $A$, Zimmermann $M$, Gadner $H$, Stanulla $M$, Dördelmann M, Löning L, Beier R, Ludwig WD, Ratei R, Harbott J, Boos J, Mann G, Niggli $F$, Feldges $A$, Henze $G$, Welte $K$, Beck JD, Klingebiel T, Niemeyer $C$, Zintl F, Bode U, Urban C, Wehinger H, Niethammer D, Riehm H, Schrappe M; German-Austrian-Swiss ALL-BFM Study Group. Risk-adjusted therapy of acute lymphoblastic leukemia can decrease treatment burden and improve survival: treatment results of 2169 unselected pediatric and adolescent patients enrolled in the trial ALL-BFM 95. Blood 2008;111:4477-4489.

5. Silverman LB, Gelber RD, Dalton VK, Asselin BL, Barr RD, Clavell LA, Hurwitz CA, Moghrabi A, Samson Y, Schorin MA, Arkin S, Declerck L, Cohen HJ, Sallan SE. Improved outcome for children with acute lymphoblastic leukemia: results of Dana-Farber Consortium Protocol 91-01. Blood 2001;97:12111218.

6. DeAngelo DJ, Stevenson KE, Dahlberg SE, Silverman LB, Couban S, Supko JG, Amrein PC, Ballen KK, Seftel MD, Turner AR, Leber B, Howson-Jan K, Kelly K, Cohen S, Matthews JH, Savoie L, Wadleigh M, Sirulnik LA, Galinsky I, Neuberg DS, Sallan SE, Stone RM. Long-term outcome of a pediatricinspired regimen used for adults aged 18-50 years with newly diagnosed acute lymphoblastic leukemia. Leukemia 2015;29:526-534.

7. Larson RA, Dodge RK, Burns CP, Lee EJ, Stone RM, Schulman P, Duggan D, Davey $F R$, Sobol RE, Frankel SR. A five-drug remission induction regimen with intensive consolidation for adults with acute lymphoblastic leukemia: Cancer and Leukemia Group B study 8811. Blood 1995;85:2025-2037.

8. Linker C, Damon L, Ries C, Navarro W. Intensified and shortened cyclical chemotherapy for adult acute lymphoblastic leukemia. J Clin Oncol 2002;20:2464-2471.

9. Rowe JM, Buck G, Burnett AK, Chopra R, Wiernik PH, Richards SM, Lazarus HM, Franklin IM, Litzow MR, Ciobanu N, Prentice HG, Durrant J, Tallman MS, Goldstone AH; ECOG; MRC/NCRI Adult Leukemia Working Party. Induction therapy for adults with acute lymphoblastic leukemia: results of more than 1500 patients from the international ALL trial: MRC UKALL XII/ECOG E2993. Blood 2005;106:3760-3767.

10. Gökbuget N, Arnold R, Böhme A, Fietkau R, Freund M, Ganser A, Kneba M, Lipp T, Ludwig WD, Maschmeyer G, Messerer D, Rieder $H_{\text {, Thiel }}$, Hoelzer D; German Multicenter Study Group for Adult ALL (GMALL). Treatment of adult ALL according to protocols of the German Multicenter Study Group for Adult ALL (GMALL). In: Estey EH, Faderl SH, Kantarjian HM (eds). Acute Leukemias. Berlin, Springer, 2008.

11. Kantarjian HM, O'Brien S, Smith TL, Cortes J, Giles FJ, Beran M, Pierce S, Huh Y, Andreeff M, Koller C, Ha CS, Keating MJ, Murphy S, Freireich EJ. Results of treatment with hyper-CVAD, a dose-intensive regimen, in adult acute lymphocytic leukemia. J Clin Oncol 2000;18:547-561.

12. Mead GM, Sydes MR, Walewski J, Grigg A, Hatton CS, Pescosta N, Guarnaccia C, Lewis MS, McKendrick J, Stenning SP, Wright D; UKLG LY06 collaborators. An international evaluation of CODOX-M and CODOX-M alternating with IVAC in adult Burkitt's lymphoma: results of United Kingdom Lymphoma Group LY06 study. Ann Oncol 2002;13:1264-1274.

13. Pfreundschuh $M$, Trümper $L$, Kloess $M$, Schmits $R$, Feller AC, Rudolph $C$, Reiser M, Hossfeld DK, Metzner B, Hasenclever D, Schmitz N, Glass B, Rübe C, Loeffler M; German High-Grade Non-Hodgkin's Lymphoma Study Group. Two-weekly or 3-weekly CHOP chemotherapy with or without etoposide for the treatment of young patients with good-prognosis (normal LDH) aggressive lymphomas: results of the NHL-B1 trial of the DSHNHL. Blood 2004;104:626-633.

14. Huguet $F$, Leguay $T$, Raffoux $E$, Thomas $X$, Beldjord $K$, Delabesse $E$, Chevallier $P$, Buzyn A, Delannoy A, Chalandon $Y$, Vernant JP, Lafage-Pochitaloff $M$, Chassevent $A$, Lhéritier $V$, Macintyre $E$, Béné $M C$, Ifrah $N$, Dombret $H$. Pediatric-inspired therapy in adults with Philadelphia chromosomenegative acute lymphoblastic leukemia: the GRAALL-2003 study. J Clin Oncol 2009;27:911-918.

15. Pastore D, Specchia G, Carluccio P, Liso A, Mestice A, Rizzi R, Greco G, Buquicchio $C$, Liso V. FLAG-IDA in the treatment of refractory/relapsed acute myeloid leukemia: single-center experience. Ann Hematol 2003;82:231235.

16. Schwartz $P$, Hunault-Berger $M$, Chevallier P. French results with the EWALL chemotherapy backbone in older patients with Philadelphia chromosomenegative acute lymphoblastic leukemia. A GRAALL report. Haematologica 2013;98:463.

17. Wiernik $P H$, Serpick AA. A randomized clinical trial of daunorubicin and a combination of prednisone, vincristine, 6-mercaptopurine, and methotrexate in adult acute nonlymphocytic leukemia. Cancer Res 1972;32:2023-2026.

18. Pulte $\mathrm{D}$, Gondos $\mathrm{A}$, Brenner $\mathrm{H}$. Improvement in survival in younger patients with acute lymphoblastic leukemia from the 1980s to the early 21st century. Blood 2009;113:1408-1411.

19. Vitale A, Guarini A, Chiaretti $S$, Foà R. The changing scene of adult acute lymphoblastic leukemia. Curr Opin Oncol 2006;18:652-659.

20. Pui CH, Evans WE. Treatment of acute lymphoblastic leukemia. N Engl J Med 2006;354:166-178.

21. Moorman AV, Chilton L, Wilkinson J, Ensor HM, Bown N, Proctor SJ. A population-based cytogenetic study of adults with acute lymphoblastic leukemia. Blood 2010;115:206-214. 
22. Houot $\mathrm{R}$, Tavernier $\mathrm{E}$, Le $\mathrm{QH}$, Lhéritier $\mathrm{V}$, Thiebaut $\mathrm{A}$, Thomas X. Philadelphia chromosome-positive acute lymphoblastic leukemia in the elderly: prognostic factors and treatment outcome. Hematology 2004;9:369-376.

23. Gokbuget N, Hoelzer D, Arnold R, Böhme A, Bartram CR, Freund M, Ganser A, Kneba M, Langer W, Lipp T, Ludwig WD, Maschmeyer G, Rieder H, Thiel E, Weiss A, Messerer D. Results of a shortened, dose reduced treatment protocol in elderly patients with acute lymphoblastic leukemia (ALL). Blood 2000;96:718-719.

24. Pagano L, Mele L, Trape G, Leone G. The treatment of acute lymphoblastic leukaemia in the elderly. Leuk Lymphoma 2004;45:117-123.

25. Martell MP, Atenafu EG, Minden MD, Schuh AC, Yee KW, Schimmer $A D$, Gupta V, Brandwein JM. Treatment of elderly patients with acute lymphoblastic leukaemia using a paediatric-based protocol. Br J Haematol 2013;163:458-464.

26. Rousselot $P$, Coudé $M M$, Gokbuget $N$, Gambacorti Passerini $C$, Hayette $S$, Cayuela JM, Huguet $F$, Leguay $T$, Chevallier $P$, Salanoubat $C$, Bonmati $C$, Alexis $M$, Hunault $M$, Glaisner $S$, Agape $P$, Berthou $C$, Jourdan E, Fernandes J, Sutton L, Banos A, Reman O, Lioure B, Thomas X, Ifrah N, Lafage-Pochitaloff $M$, Bornand A, Morisset L, Robin V, Pfeifer H, Delannoy A, Ribera J, Bassan R, Delord M, Hoelzer D, Dombret H, Ottmann OG; European Working Group on Adult ALL (EWALL) group. Dasatinib and low-intensity chemotherapy in elderly patients with Philadelphia chromosome-positive ALL. Blood 2016;128:774-782.

27. Vignetti M, Fazi P, Cimino G, Martinelli G, Di Raimondo F, Ferrara F, Meloni G, Ambrosetti A, Quarta G, Pagano L, Rege-Cambrin G, Elia L, Bertieri R, Annino $L$, Foà $R$, Baccarani M, Mandelli F. Imatinib plus steroids induces complete remissions and prolonged survival in elderly Philadelphia chromosomepositive patients with acute lymphoblastic leukemia without additional chemotherapy: results of the Gruppo Italiano Malattie Ematologiche dell'Adulto (GIMEMA) LAL0201-B protocol. Blood 2007;109:3676-3678.

28. Pui CH, Mullighan CG, Evans WE, Relling MV. Pediatric acute lymphoblastic leukemia: where are we going and how do we get there? Blood 2012;120:1165-1174.

29. Riehm H, Gadner H, Henze G, Langermann HJ, Odenwald E. The Berlin childhood acute lymphoblastic leukemia therapy study, 1970-1976. J Pediatr Hematol Oncol 1980;2:299-306.
30. Gaynon PS, Steinherz PG, Bleyer WA, Ablin AR, Albo VC, Finklestein JZ, Grossman NJ, Littman PS, Novak LT, Pyesmany AF, Sather HN, Hammond GD. Intensive therapy for children with acute lymphoblastic leukaemia and unfavourable presenting features: early conclusions of study CCG-106 by the Childrens Cancer Study Group. Lancet 1988;332:921-924.

31. Malhotra $P$, Varma $S$, Varma $N$, Kumari $S$, Das $R$, Jain $S$, Ahluwalia J, Mahi S, Sharma SC, Radhika S. Outcome of adult acute lymphoblastic leukemia with BFM protocol in a resource-constrained setting. Leuk Lymphoma 2007;48:1173-1178.

32. Chang JE, Medlin SC, Kahl BS, Longo WL, Williams EC, Lionberger J, Kim K, Kim J, Esterberg E, Juckett MB. Augmented and standard Berlin-FrankfurtMünster chemotherapy for treatment of adult acute lymphoblastic leukemia. Leuk Lymphoma 2008;49:2298-2307.

33. Boissel $N$, Auclerc MF, Lhéritier $V_{1}$ Perel $Y$, Thomas $X$, Leblanc $T$, Rousselot P, Cayuela JM, Gabert J, Fegueux N, Piguet C, Huguet-Rigal F, Berthou C, Boiron JM, Pautas C, Michel G, Fière D, Leverger G, Dombret $H$, Baruchel A. Should adolescents with acute lymphoblastic leukemia be treated as old children or young adults? Comparison of the French FRALLE-93 and LALA94 trials. J Clin Oncol 2003;21:774-780.

34. de Bont JM, Holt Bv, Dekker AW, van der Does-van den Berg A, Sonneveld $P$, Pieters R. Significant difference in outcome for adolescents with acute lymphoblastic leukemia treated on pediatric vs adult protocols in the Netherlands. Leukemia 2004;18:2032-2035.

35. Marks DI, Paietta EM, Moorman AV, Richards SM, Buck G, DeWald G, Ferrando A, Fielding AK, Goldstone AH, Ketterling RP, Litzow MR, Luger SM, McMillan AK, Mansour MR, Rowe JM, Tallman MS, Lazarus HM. T-cell acute lymphoblastic leukemia in adults: clinical features, immunophenotype, cytogenetics, and outcome from the large randomized prospective trial (UKALL XII/ECOG 2993). Blood 2009;114:5136-5145.

36. Stock W, Luger SM, Advani AS, Geyer S, Harvey RC, Mullighan CG, Willman CL, Malnassy G, Parker E, Laumann KM, Sanford B, Marcucci G, Paietta EM, Liedtke M, Claxton DF, Foster MC, Appelbaum FR, Erba H, Litzow MR, Tallman MS, Stone RM, Larson RA. Favorable outcomes for older adolescents and young adults (AYA) with acute lymphoblastic leukemia (ALL): early results of US Intergroup Trial C10403. Blood 2014;124:796. 